\title{
Emergency nurses' preparedness for disaster in the Kingdom of Saudi Arabia
}

\author{
Badryah Alshehri * \\ Saudi Ministry of Health, Riyadh, King Saud Medical City, Saudi Arabia
}

Received: March 29, 2016

Accepted: September 28, $2016 \quad$ Online Published: November 13, 2016

DOI: $10.5430 /$ jnep.v7n3p101

URL: http://dx.doi.org/10.5430/jnep.v7n3p101

\begin{abstract}
Background and objective: The Kingdom of Saudi Arabia has recently faced many man-made and natural disasters. Since disaster victims are transferred to hospitals, nurses are among the first health care providers to respond to an emergency. Therefore, to improve disaster management it is essential to examine the current state of nurses' preparedness. The aim of the study was attempts to determine the disaster preparedness of emergency nurses in Saudi Arabia.

Methods: The study data were collected using two survey tools from the research literature, and 72 participants were recruited from two government hospitals in Riyadh. The response rate was $31.7 \%$.

Results: The study revealed that most nurses understood their roles after reading the disaster plan. Although half of the respondents had completed training in the previous 12 months, only $60 \%$ answered the item related to confidence after training. There was a significant difference between the confidence of those who had participated in a disaster or mass casualties training program and that of those who had not. Only $26 \%$ answered the item related to confidence after being involved in a real disaster, and no significant difference was found between the confidence of those who had attended a real disaster or mass casualties event and that of those who had not.

Conclusions: The study found that respondents had minimal and limited disaster experience, as reflected in their low levels of confidence after being involved in real disaster events. This highlights the need for continued efforts to expand disaster training and ensure that nurses are appropriately prepared.
\end{abstract}

Key Words: Emergency nurse, Preparedness, Disaster, Education, Training

\section{INTRODUCTION}

Disaster is unpredictable and can strike at any time and place, severely damaging the functioning and structure of local communities as well as the natural environment. ${ }^{[1]}$ A disaster occurs when a hazard threatens people's safety and lives, causing them to require external assistance. ${ }^{[2]}$ A report from the Centre for Research on the Epidemiology of Disasters recorded that 6,873 natural disasters occurred worldwide between 1994 and 2013, with 218 million people affected every year. ${ }^{[3]}$

Whether disasters are natural, man-made or mass casualty events, they present a significant challenge both to communities and to the organisations responsible for responding. ${ }^{[4]}$ Appropriate disaster management should be based on a clear plan, preparedness and collaborative and effective efforts on the part of the community and the various responding organisations. ${ }^{[5]}$ Health care systems, represented by hospitals, are on the front lines of emergency response and attempt to help Arabia.

*Correspondence: Badryah Alshehri; Email: baa325@gmail.com; Address: Saudi Ministry of Health, Riyadh, King Saud Medical City, Saudi 
people and communities recover from disasters. ${ }^{[6]}$

When disasters occur hospitals continue to operate to provide victims with appropriate care. ${ }^{[5]}$ Preparedness should thus involve all health care providers working in EDs, including physicians, nurses, technicians and paramedics. ${ }^{[7]}$ Nurses are the largest working group in the hospital system. ${ }^{[8]}$

International studies have revealed nurses' preparedness for disaster. Several studies agree that nurses are poorly prepared for disasters by their planning, education, training and responses. ${ }^{[9-25]}$ Nurses must know the relevant disaster emergency plan to be familiar with and recognise their role when an event requires them to respond. ${ }^{[9,10,14,16,24]}$ A clear disaster plan will inform nurses of their chain of command. Hammad et al. ${ }^{[16]}$ found that nurses were confused about their role in disaster planning. Hammad et al. ${ }^{[16]}$ found that the participants were not adequately prepared as they lacked disaster knowledge; they further emphasised the importance of nurse preparedness as nurses are on the front lines when there is a disaster. In assessing the role of nurses in disasters, Whetzel et al. ${ }^{[24]}$ found that, while the majority of respondents knew that their hospital had a disaster plan, few knew where it was located and others did not know of the existence of a hospital disaster plan. Thus, the researchers concluded that preparedness not only involves nurses knowing the location of the disaster plan, but also knowing their roles in it.

In addition, Al-Khalaileh et al. ${ }^{[9]}$ found that nurses rated themselves as poorly prepared to create and draft guidelines for disaster and emergency planning. Nurses who knew their disaster plan did not feel confident that their workplaces would implement the disaster plan. Usher et al., ${ }^{[22]}$ revealed that nurses from countries in the Asia-Pacific region were poorly trained in emergency planning, while nurses from Cambodia considered themselves poorly prepared to create new guidelines and emergency plans.

Fung et al. ${ }^{[15]}$ pointed out that, while the majority of nurses knew the protocols of their disaster plan, a few nurses had not read the plan and others did not know if they had a disaster plan in the first place. In addition, less than half of the respondents stated that they would follow the hospital protocol, and others stated that they would wait for instructions from their supervisors before responding to disasters. Further, Veenema et al. ${ }^{[26]}$ revealed a weak relationship between nurses' knowledge and their willingness to respond to radiological events.

The preparedness of nurses to respond to chemical, biological, radiological and nuclear events is an issue of global importance. Yet, gaps in knowledge were found when inves- tigating the education and training of nurses in these specific areas. ${ }^{[9,19]}$ Al-Khalaileh et al., ${ }^{[9]}$ Al-Thobaity et al. ${ }^{[10]}$ and Usher et al. ${ }^{[22]}$ showed that nurses were poorly prepared for biological threats. The respondents in these three studies reported that they were willing to attend education and training sessions on disasters. Similarly, Mitchell et al. ${ }^{[19]}$ revealed that nurses were willing to receive education and training regarding chemical, biological, radiological and nuclear events. In a study conducted by Rassin et al., ${ }^{[21]}$ respondents rated themselves as having a low level of preparedness for chemical and radiological disaster events. Rassin et al. asserted that early preparation affects the ability of nurses to respond effectively to a disaster. Veenema et al. ${ }^{[26]}$ revealed that participants in their study knew about different types of radiation burns but did not know what procedures to follow. The respondents also indicated that they need further training in relation to exposure and protecting themselves and others from contamination.

In an interesting study carried out to assess the future capacity of nurses to respond during bushfire emergencies, Ranse, Lenson et al. ${ }^{[20]}$ found that nurses had no basic knowledge of how to manage a bushfire emergency, having been trained to manage disasters that rarely occurred in their area (e.g., mock airport incidents). They also found that nurses were confused regarding their administrative role, and suggested that nurses should be prepared to play various roles in disaster management, especially those related to administration.

Fung et al. ${ }^{[15]}$ found that participants in their study believed disaster management training and drills to be useful. In particular, the participants agreed that disaster training should include certain additional courses, such as first aid, basic and advanced cardiovascular life support, infection control, advanced trauma care nursing and post-traumatic psychological care. Other studies concluded that drills and continuous education courses would increase nurses' knowledge of disasters and ensure their preparedness by increasing their confidence and ability to manage any disaster event. ${ }^{[9,10,22]}$

Having found that hospital-based training was the most common source of disaster education, Hammad et al. ${ }^{[16]}$ stated that the content of education programs provided by hospitals differed from one hospital to another based on the lecturers' backgrounds, their qualifications and the frequency with which they ran these sessions. Hammad et al. highlighted that these hospital sessions were found to meet nurses' needs. In a study by Usher et al., ${ }^{[22]}$ participating registered nurses (RNs) from the Asia-Pacific region reported moderate to high levels of interest in attending educational courses. However, RNs from Bangladesh, Bhutan, China and the Solomon Islands reported low attendance at continuing edu- 
cation courses in disaster preparedness, and were found to attend such courses infrequently.

All authors included in this review agreed on the importance of disaster drills to improve nurses' self-confidence, as a high level of confidence is necessary to respond appropriately to a disaster event. Manley et al. ${ }^{[17]}$ found that nurses felt more confident dealing with the victim of a cardiac emergency or motor vehicle accident than with victims affected by chemical weapons or a terrorist attack. Duong ${ }^{[14]}$ indicated that the respondents in her study reported different levels of confidence regarding their preparedness for disasters and mass casualties.

Arbon, Ranse, et al. ${ }^{[12]}$ found no significant positive relationship between the confidence of nurses who attended disaster education courses and that of those who attended a real disaster. The researchers added that nurses with experience in dealing with different types of disasters were more willing to respond to disaster events. Further, nurses who work fulltime were found to be more confident or willing to respond than those who work part-time.

Nurses' knowledge and perceptions of personal safety influences their confidence in responding to a radiation emergency, as reported by Veenema et al., ${ }^{[26]}$ who found a positive correlation between nurses' baseline knowledge and their perceptions of personal safety. Baack and Alfred ${ }^{[13]}$ found that nurses were unprepared for disasters and were not confident in responding to a major disaster. Confidence was found to be a critical attribute of those attending a real disaster. For example, in a study by Usher et al. ${ }^{[22]}$ nurses from Bangladesh and Laos indicated that they were unable to take care of disaster victims without being supervised by a physician.

The Kingdom of Saudi Arabia (KSA) has faced many manmade and natural disasters, ${ }^{[27]}$ including floods, earthquakes and pandemic diseases like influenza A (H1N1) ${ }^{[28]}$ and Middle East respiratory syndrome coronavirus. ${ }^{[29]}$ Man-made risks with the potential to result in disaster and mass casualties include religious gatherings such as $\mathrm{Al} \mathrm{Hajj}$ and $\mathrm{Al}$ $\mathrm{Omrah}^{[27,30]}$ and terrorist attacks. ${ }^{[27]}$

The current study aims to examine the disaster preparedness of emergency nurses working in health services in Saudi Arabia using the following methods:

(1) Identifying the level of education and training of emergency nurses.

(2) Determining their level of confidence in responding to a disaster.

\section{Methodology}

\subsection{Research design}

This is a descriptive study design and data was collected using a survey. ${ }^{[31]}$

\subsection{Study instrument}

A survey tool incorporated questions similar to those used by Duong, ${ }^{[14]}$ Hammad et al. ${ }^{[16]}$ in their studies of Australian emergency nurses' knowledge and perceptions of their roles in disaster response, was developed. Permission to use the questionnaires was granted from the primary authors. A panel of experts in a major disaster established the validity of the new developed survey. The survey included 23 items and divided into three sections: 1) demographic data, 2) disaster preparedness, and 3) disaster education and training and were consistent with Saudi Arabia nursing practice and culture (see Table 1).

\subsection{Sample}

This study was conducted in two hospitals located in Riyadh. Nurses who were working in an ED at the time of data collection, had at least one year's work experience in the ED and could read and write English were considered eligible to participate.

\subsection{Distribution and return of questionnaires}

One hundred questionnaires were distributed in the EDs of each of the two targeted hospitals. The estimated number of ED staff nurses was 150 at Hospital A and 77 at Hospital $\mathrm{B}$, yielding a total of 227 staff. It is understood that the questionnaire was distributed to all staff but, of the 130 questionnaires returned, 58 were excluded because respondents did not meet the inclusion criteria for the study. The remaining 72 questionnaires were completed by respondents who met the inclusion criteria, yielding an estimated response rate of $31.7 \%$ (see Table 2).

\subsection{Demographic characteristics}

The majority of the respondents were female (88.7\%) with a median age of 31 years ( $\mathrm{IQR}=28$ to 39 ). The proportion of non-Saudi respondents was $91.7 \%$. The median year for initial nursing registration was 2005 (IQR 1996 to 2008). Most of the respondents (91.7\%) worked 48 hours per week. The majority (76.4\%) had a bachelor's degree, and $57.7 \%$ had completed their initial nursing training somewhere other than in the KSA. Over $70 \%$ of the respondents were RNs, and the rest held other positions in the ED. Of those who responded to the optional question about where they worked, $29.5 \%$ reported the paediatric ED, $22.7 \%$ reported the adult ED and the remainder listed other ED areas (see Table 3). 
Table 1. The current study questionnaire

Emergency Nurses' Preparedness for Disaster in the Kingdom of Saudi Arabia Questionnaire

Part 1 Demographic data

Please complete your details for the following items.

1. Gender

$\square$ Male

$\square$ Female

2. Age...............

3. Nationality

$\square$ Saudi

$\square$ Non-Saudi Nationality (optional)

4. What year were you first registered as a nurse?

5. What qualification/s level/s have you achieved?

$\square$ Diploma $\quad \square$ Bachelor $\square$ Masters $\square \mathrm{PhD}$

6. Did you complete your initial nursing training in Saudi Arabia?

$\square$ Yes $\square$ No

7. Most of the time, in what emergency department do you currently work?

8. How many hours per week are you working? (Optional)

9. What is your current role in the emergency department?

$\square$ General Registered Nurse $\quad \square$ Clinical Nurse Educator

$\square$ Registered Nurse Specialist $\quad \square$ Clinical Nurse Consultant

$\square$ Nurse Manager Clinical Nurse

$\square$ Other (please state).

Part 2 Disaster preparedness

10. Do you know where your emergency department disaster plan is kept?

$\square$ Yes $\square$ No

11. Have you read your Emergency Department disaster plan? (for the ED response)

$\square$ Yes, and I understand my role in it $\quad \square$ Yes and I do not understand my role in it

$\square$ No $\quad \square$ I did not know we had one

12. Have you read the Major Incident Plan ( for the whole hospital response) ?

$\square$ Yes and I understand my role in it $\quad \square$ Yes and I do not understand my role in it

$\square$ No

Part 3 Disaster education and training

13. On a scale of 0 - 5 , how confident do you feel that you are prepared and trained to respond to a disaster event? Not at all 0 Extremely confident

14. On a scale of 0 - 5 , how confident do you feel that you are prepared and trained for mass casualties? Not at all
Extremely confident

0 1

2

15. Have you ever been involved in a disaster exercise in your emergency department?

$\square$ Yes $\square$ No

16. When did you last attend disaster training?

$\square$ I have not had any $\quad \square$ In the last 12 months

$\square$ Between 12 months and 2 years $\quad \square$ More than 2 years ago

17. In addition to the above what emergency or disaster based additional training education have you completed or are currently undertaking?

$\square$ Hospital education sessions $\quad \square$ Emergency incident medical Saudi courses

$\square$ Online education $\quad \square$ Post graduate studies (e.g. on line courses)

$\square$ Other (pleas state) ..................................................

18. Have you received payment to attend or other financial support for the following types of disaster education by any employer in KSA?

$\square$ Hospital education sessions $\quad \square$ Emergency incident medical Saudi courses

$\square$ Online education $\quad \square$ Post graduate studies (e.g. on line courses)

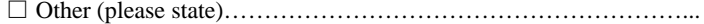

19. Through which institution did you undertake this training? (e.g. tertiary, private organisation)

……........................................................... (Optional)

20. Have you, in your work experience, been involved in a disaster?

$\square$ Yes $\quad \square$ No

If yes, please answer items $a, b$, and c.

a) What was the disaster? (e.g. transport incident, natural disaster)

b) Where was the disaster?

c) When was the disaster?

21. How often does your emergency department have disaster training (i.e. in service, lectures, desk top exercises, real-time exercises)?

$\square$ None $\quad \square$ Twice per year or more often

$\square$ Annually $\quad \square$ Once every 2 years

$\square$ Other (please state)

22. On a scale of 0 - 5, how important do you think it is for nurses in the Emergency Department to have disaster training?
Not at all
Extremely important

$\mathbf{0}$

1

2

23. Any other comments/suggestions in relation to your training or potential training in disaster nursing care?

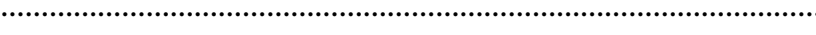

Thank you for taking the time to complete this survey.

Please return completed survey to the box in the staff room 
Table 2. Response rate

\begin{tabular}{llll}
\hline Hospital & $\begin{array}{l}\text { Target } \\
\text { population size }\end{array}$ & $\begin{array}{l}\text { Valid } \\
\text { responses }\end{array}$ & $\begin{array}{l}\text { Response } \\
\text { rate }\end{array}$ \\
\hline Hospital A & 150 & 51 & $34 \%$ \\
Hospital B & 77 & 21 & $27.3 \%$ \\
TOTAL & 227 & 72 & $31.7 \%$ \\
\hline
\end{tabular}

Table 3. Demographic characteristics $(n=72)^{*}$

\begin{tabular}{|c|c|c|}
\hline Demographics & $N$ & $\%$ \\
\hline \multicolumn{3}{|l|}{ Gender $(n=71)$} \\
\hline Female & 63 & 88.7 \\
\hline Male & 8 & 11.3 \\
\hline \multicolumn{3}{|l|}{ Age $(n=67)$} \\
\hline 23-30 & 32 & 47.8 \\
\hline $31-40$ & 22 & 32.8 \\
\hline$>41$ & 13 & 19.4 \\
\hline \multicolumn{3}{|l|}{ Nationality $(n=71)$} \\
\hline Saudi & 5 & 7.0 \\
\hline Non-Saudi & 66 & 93.0 \\
\hline \multicolumn{3}{|c|}{ First year registered $(n=64)$} \\
\hline$<1996$ & 16 & 25.0 \\
\hline 1996-2000 & 8 & 12.5 \\
\hline 2001-2005 & 14 & 21.9 \\
\hline 2006-2010 & 25 & 39.0 \\
\hline 2011-2015 & 1 & 1.6 \\
\hline \multicolumn{3}{|l|}{ Qualifications } \\
\hline High school diploma & 15 & 20.8 \\
\hline Bachelor’s & 55 & 76.4 \\
\hline Master’s & 2 & 2.8 \\
\hline \multicolumn{3}{|c|}{ Initial training in the KSA $(n=71)$} \\
\hline Yes & 30 & 42.3 \\
\hline No & 41 & 57.7 \\
\hline \multicolumn{3}{|c|}{ Clinical area in the ED $(n=44)$} \\
\hline Adult & 10 & 22.7 \\
\hline Triage & 1 & 2.3 \\
\hline Paediatric & 13 & 29.5 \\
\hline Resuscitation & 2 & 4.5 \\
\hline $\mathrm{OB} / \mathrm{GYN}$ & 3 & 6.8 \\
\hline Observation & 3 & 6.8 \\
\hline Other & 12 & 27.3 \\
\hline \multicolumn{3}{|l|}{ Working hours } \\
\hline 40 & 1 & 1.4 \\
\hline 45 & 2 & 2.8 \\
\hline 48 & 66 & 91.6 \\
\hline 50 & 2 & 2.8 \\
\hline 56 & 1 & 1.4 \\
\hline \multicolumn{3}{|l|}{ Position in the $\operatorname{ED}(n=70)$} \\
\hline General RN & 50 & 71.4 \\
\hline Clinical nurse educator & 2 & 2.9 \\
\hline RN specialist & 17 & 24.3 \\
\hline Other & 1 & 1.4 \\
\hline
\end{tabular}

*Denominator varies because of missing values

\subsection{Ethical issues and considerations}

Before this study was conducted, ethical approval was obtained from the Saudi Ministry of Health.

\subsection{Data collection}

A total of 200 questionnaires were distributed. The completed questionnaires were placed in a box in each staff room and the head nurses delivered the boxes to the researcher after two months. There were two questionnaires used and combined them into one questionnaire. The original questionnaires were developed and validated by the same author (Hammad, née Duong), ${ }^{[14,16]}$ who granted permission for this study to use the questionnaires. Of the original questions, which were written for courses in Australia, only 23 questions were taken from the original which is fit to use for nurses in the KSA. Two of questions have been changed to fit courses in the KSA. Three subject matter experts were assigned to review the changes to the original questionnaire.

\subsection{Data analysis}

The data were entered into an Excel spreadsheet, which was cross-checked with the questionnaires. The data were then exported from Excel to SPSS (version 22). Descriptive statistics such as frequencies, percentages, the median and the inter-quartile range (IQR) were used to analyse the demographic data. In addition, the Mann-Whitney $U$ Test was used to assess Likert scale responses. The purpose was to compare group means, ${ }^{[32]}$ and determine if any significant relationships exist. This study investigated the differences between (i) those who had been involved in disaster training and those who had not, and (ii) those who had been involved in a disaster experience and those who had not. Finally, the open-ended questions were analysed by coding them in SPSS. The following sections present the details and results of the analyses.

\section{RESULTS}

There were seventh subcategories determined nurses' preparedness in disaster in KSA. "reading of the disaster plan", " disaster preparedness training", "attendance at actual disasters", "respondents' level of confidence", "comparing the two independent variables relating to preparedness and response to disaster events", "The importance of disaster training to those with and without real experience and with or without training", and "respondents' recommendations".

\subsection{Reading of the disaster plan}

Almost all of the respondents (95\%) knew the location of the ED disaster plan. A slightly smaller percentage (91\%) had also read the plan and understood their role in disaster management. A minority (2.8\%) responded that they had read 
the plan but did not understand their role in it (see Figure 1).

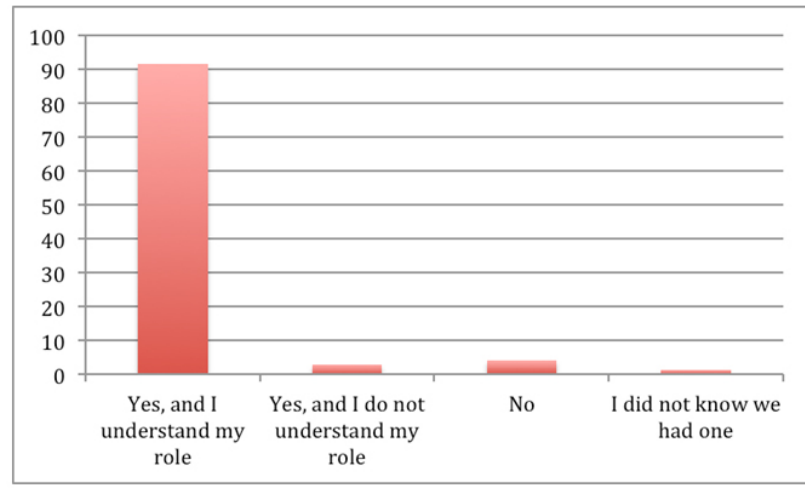

Figure 1. Responses to having read the disaster plan $(\mathrm{n}=$ 71)

With regard to the major incident plan, $73.5 \%$ of the respondents had read it and understood their role in it. A small proportion $(8.8 \%)$ had read the plan but did not understand their role in it (see Figure 2).

\subsection{Disaster preparedness training}

Roughly two-thirds (63.2\%) of respondents stated that they had undertaken disaster training provided at their hospital,
$50 \%$ stated that they had attended disaster training within the last 12 months and 52\% reported that they did not receive payment for attending these courses. Others (41.5\%) reported receiving payment to attend the hospital education sessions, and 55\% had taken disaster courses in tertiary hospitals. Regarding the regularity of this training, the most frequent response $(63.2 \%)$ was that it had occurred annually (see Table 4).

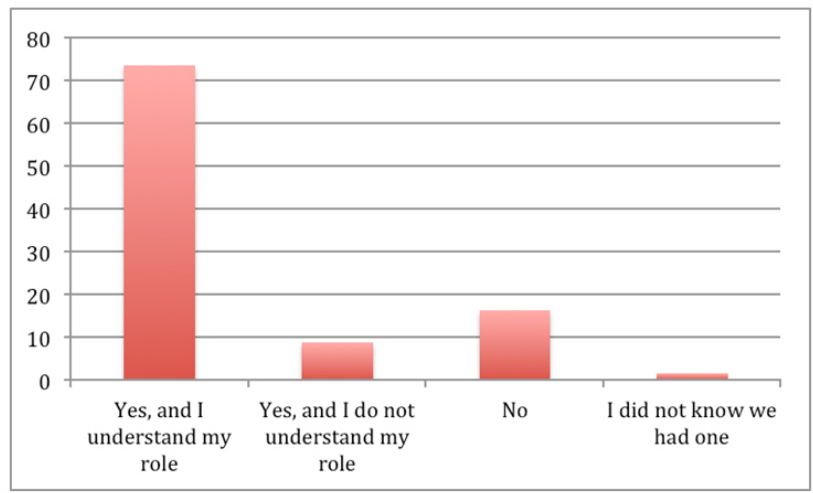

Figure 2. Responses to having read the major incident plan $(n=68)$

Table 4. Sources of disaster training

\begin{tabular}{|c|c|c|}
\hline Sources of disaster preparedness training & $N^{*}$ & $\%$ \\
\hline \multicolumn{3}{|l|}{ Attendance at hospital disaster training $(n=68)$} \\
\hline I have not had any & 7 & 10.3 \\
\hline In the last 12 months & 34 & 50.0 \\
\hline Between 12 months and 2 years ago & 19 & 27.9 \\
\hline More than 2 years ago & 8 & 11.8 \\
\hline \multicolumn{3}{|l|}{ Sources of training education $(n=68)$} \\
\hline Hospital education sessions & 43 & 63.2 \\
\hline Hospital education sessions and online education & 8 & 11.8 \\
\hline Online education & 6 & 8.8 \\
\hline Other & 6 & 8.8 \\
\hline Hospital education sessions/Saudi medical emergency incident course & 2 & 2.9 \\
\hline Hospital education sessions and other & 1 & 1.5 \\
\hline Postgraduate studies (e.g., online courses) & 1 & 1.5 \\
\hline Saudi emergency medical incident courses & 1 & 1.5 \\
\hline \multicolumn{3}{|l|}{ Paid training $(n=53)$} \\
\hline Hospital education sessions & 22 & 41.5 \\
\hline Online education & 2 & 3.8 \\
\hline Did not receive payment & 28 & 52.8 \\
\hline Hospital education sessions and online education & 1 & 1.9 \\
\hline \multicolumn{3}{|l|}{ Institution at which training was undertaken $(n=20)$} \\
\hline Tertiary & 11 & 55 \\
\hline Private organisation & 4 & 20 \\
\hline College & 1 & 5 \\
\hline Ministry of Health & 2 & 10 \\
\hline King Fahad Medical City & 2 & 10 \\
\hline \multicolumn{3}{|l|}{ Frequency of disaster training $(n=68)$} \\
\hline None & 4 & 5.9 \\
\hline Twice per year or more often & 19 & 26.5 \\
\hline Annually & 43 & 63.2 \\
\hline Once every 2 years & 3 & 4.4 \\
\hline
\end{tabular}

*Denominator varies because of missing values 


\subsection{Attendance at actual disasters}

Of the respondents who had been involved in an actual disaster, $42.9 \%$ had faced mass casualties (in a transport incident for example), and $35.7 \%$ had experienced a natural disaster, such as a flood. The majority (81.8\%) of these incidents had occurred in Riyadh. Almost 56\% of respondents who had experienced disasters had attended the incidents in 2014 (see Table 5).

Table 5. Summary of respondents' disaster experience

\begin{tabular}{|c|c|c|}
\hline Disaster characteristics & $\mathbf{N}^{*}$ & $\%$ \\
\hline \multicolumn{3}{|l|}{ Type $(n=14)$} \\
\hline Transport incidents & 6 & 42.9 \\
\hline Natural disaster & 5 & 35.7 \\
\hline Mass casualties & 1 & 7.1 \\
\hline Transport incidents and mass casualties & 1 & 7.1 \\
\hline Transport incidents, smoke inhalation, food poisoning and burns & 1 & 7.1 \\
\hline \multicolumn{3}{|l|}{ Location $(n=11)$} \\
\hline Riyadh & 9 & 81.8 \\
\hline Jeddah & 1 & 9.1 \\
\hline Riyadh and the Philippines & 1 & 9.1 \\
\hline \multicolumn{3}{|l|}{ Year $(n=9)$} \\
\hline 2003 & 1 & 11.1 \\
\hline 2010 & 1 & 11.1 \\
\hline 2012 & 1 & 11.1 \\
\hline 2013 & 1 & 11.1 \\
\hline 2014 & 5 & 55.6 \\
\hline
\end{tabular}

*Denominator varies because of missing values

\subsection{Respondents' level of confidence}

All respondents, whether or not they had been involved in disaster or mass casualty events or training, were asked to respond to a 6-point confidence-related Likert scale, with 0 being 'not at all confident' and 5 being 'extremely confident'.

\subsubsection{Respondents who had received training}

The confidence ratings of respondents who were trained in disaster or mass casualty preparation are shown in Table 6. In general, all respondents who responded to this question reported that they were confident, with similar levels of confidence reported for disasters and mass casualty events. The table shows that the vast majority of respondents (91\%) perceived training as extremely important. No respondents rated it as slightly, mildly or not at all important.

\subsubsection{Respondents who had not received training}

Table 7 shows the confidence ratings of respondents who had never been involved in disaster or mass casualty training. Interestingly, almost $85 \%$ of those who had not undertaken disaster training selected levels from confident to extremely confident. However, the confidence rating of respondents who had never been trained in managing mass casualties dropped to below $80 \%$, in contrast to the response of those who had received training (see Table 6). All respondents thought that training was either extremely important (69\%) or very important $(31 \%)$.

Table 6. Confidence levels of respondents who had participated in disaster or mass casualties training

\begin{tabular}{lllllll}
\hline & \multicolumn{5}{c}{ Confidence Level After Disaster Training } \\
\cline { 2 - 7 } & $\begin{array}{l}\text { Not at all } \\
\text { confident }\end{array}$ & $\begin{array}{l}\text { Mildly } \\
\text { confident }\end{array}$ & $\begin{array}{l}\text { Slightly } \\
\text { confident }\end{array}$ & Confident & $\begin{array}{l}\text { Very } \\
\text { confident }\end{array}$ & $\begin{array}{l}\text { Extremely } \\
\text { confident }\end{array}$ \\
\hline $\begin{array}{l}\text { After disaster training } \\
(n=43), 59.7 \%\end{array}$ & 0 & 0 & $2.3 \%$ & $34.9 \%$ & $48.8 \%$ & $14.0 \%$ \\
\hline $\begin{array}{l}\text { After mass casualties training } \\
(n=42), 58 \%\end{array}$ & 0 & 0 & $4.8 \%$ & $35.7 \%$ & $38.1 \%$ & $21.4 \%$ \\
\hline & Participants Who Had Received Training & & & \\
\cline { 2 - 7 } & Not at all & Mildly & Slightly & Important & $\begin{array}{l}\text { Very } \\
\text { important }\end{array}$ & $\begin{array}{l}\text { Extremely } \\
\text { important }\end{array}$ \\
\hline After training $(n=42), 58 \%$ & 0 & 0 & 0 & $2.4 \%$ & $7.1 \%$ & $90.5 \%$ \\
\hline
\end{tabular}




\subsubsection{Respondents' level of confidence in relation to expe- rience}

The confidence of respondents who had been involved in a disaster or mass casualties event were found to differ from that of those who had not (see Table 7).

\section{(1) Respondents previously involved in a disaster or mass casualty event}

Table 8 shows the proportion of responses under each Likert category for participants who had been involved in a disaster or mass casualty event. More than $90 \%$ were at least confident. Of those who had experienced mass casualties, less than $85 \%$ were confident, while more than $15 \%$ of respon- dents rated themselves as slightly confident. Similarly to Tables 7 and 8 shows that the vast majority of respondents thought that disaster training was extremely important.

\section{(2) Respondents who had not been involved in a disaster}

Table 9 shows that the vast majority of respondents who had not been involved in disasters $(92 \%)$ or mass casualty $(90 \%)$ reported that they were at least confident, with approximately $2 \%$ feeling not all confident in either case. Similarly, the vast majority of respondents thought that training was either extremely or very important (98\%), and the remaining $2 \%$ considered training to be important.

Table 7. Confidence level of respondents who had not participated in disaster or mass casualties training

\begin{tabular}{|c|c|c|c|c|c|c|}
\hline & \multicolumn{4}{|c|}{ Confidence Level } & \multirow[b]{2}{*}{$\begin{array}{l}\text { Very } \\
\text { important }\end{array}$} & \multirow[b]{2}{*}{$\begin{array}{l}\text { Extremely } \\
\text { confident }\end{array}$} \\
\hline & $\begin{array}{l}\text { Not at all } \\
\text { confident }\end{array}$ & $\begin{array}{l}\text { Mildly } \\
\text { confident }\end{array}$ & $\begin{array}{l}\text { Slightly } \\
\text { confident }\end{array}$ & Confident & & \\
\hline No disaster training $(n=27), 38 \%$ & $3.7 \%$ & $3.7 \%$ & $7.4 \%$ & $40.7 \%$ & $40.7 \%$ & $3.7 \%$ \\
\hline \multirow[t]{3}{*}{ No mass casualties training $(n=27), 38 \%$} & $3.7 \%$ & $3.7 \%$ & $14.8 \%$ & $40.7 \%$ & $33.3 \%$ & $3.7 \%$ \\
\hline & \multicolumn{5}{|c|}{ Participants Who Had Received Training } & \\
\hline & $\begin{array}{l}\text { Not at all } \\
\text { important }\end{array}$ & $\begin{array}{l}\text { Mildly } \\
\text { important }\end{array}$ & $\begin{array}{l}\text { Slightly } \\
\text { important }\end{array}$ & Important & $\begin{array}{l}\text { Very } \\
\text { important }\end{array}$ & $\begin{array}{l}\text { Extremely } \\
\text { important }\end{array}$ \\
\hline$(n=26), 36 \%$ & 0 & 0 & 0 & 0 & $30.8 \%$ & $69.2 \%$ \\
\hline
\end{tabular}

Table 8. Confidence level of respondents with real-life disaster or mass casualty experience

\begin{tabular}{|c|c|c|c|c|c|c|}
\hline & \multicolumn{6}{|c|}{ Confidence In Experience } \\
\hline & $\begin{array}{l}\text { Not at all } \\
\text { confident }\end{array}$ & $\begin{array}{l}\text { Mildly } \\
\text { confident }\end{array}$ & $\begin{array}{l}\text { Slightly } \\
\text { confident }\end{array}$ & Confident & $\begin{array}{l}\text { Very } \\
\text { confident }\end{array}$ & $\begin{array}{l}\text { Extremely } \\
\text { confident }\end{array}$ \\
\hline Disaster $(n=19), 26.3 \%$ & 0 & 0 & $5.3 \%$ & $42.1 \%$ & $31.6 \%$ & $21.1 \%$ \\
\hline \multirow[t]{3}{*}{ Mass casualties $(n=19), 26.3 \%$} & 0 & 0 & $15.8 \%$ & $26.3 \%$ & $36.8 \%$ & $21.1 \%$ \\
\hline & \multicolumn{6}{|c|}{ Participants Who Had Training } \\
\hline & $\begin{array}{l}\text { Not at all } \\
\text { important }\end{array}$ & $\begin{array}{l}\text { Mildly } \\
\text { important }\end{array}$ & $\begin{array}{l}\text { Slightly } \\
\text { important }\end{array}$ & Important & $\begin{array}{l}\text { Very } \\
\text { important }\end{array}$ & $\begin{array}{l}\text { Extremely } \\
\text { important }\end{array}$ \\
\hline After training $(n=19), 26.3 \%$ & 0 & 0 & 0 & 0 & $5.3 \%$ & $94.7 \%$ \\
\hline
\end{tabular}

3.5 Comparing the two independent variables relating to preparedness and response to disaster events

\subsubsection{Confidence in responding to a disaster}

A Mann-Whitney U test revealed that the confidence level (in responding to a disaster) of respondents who had been involved in ED disaster exercises was statistically significantly higher than that of those who had not $(\mathrm{Z}=-2.019, p=.04)$. These results are presented graphically in Figure 3.

However, no significant difference was found between the confidence level of respondents who had experienced a disaster event and that of those who had not $(\mathrm{Z}=-.395, p=.693)$.
These results are presented graphically in Figure 4.

\subsubsection{Confidence in responding to mass casualty events}

The confidence level of those who had been involved in ED mass casualty training exercises were statistically significantly higher than that of those who had not $(\mathrm{Z}=-2.547, p=$ $.01)$. These results are presented graphically in Figure 5.

However, a Mann-Whitney U test revealed that there was no statistically significant difference between the confidence level of respondents who had experienced mass casualties and that of those who had not $(\mathrm{Z}=-.699, p=.485)$. These results are presented graphically in Figure 6. 
Table 9. Confidence level of respondents who had not been involved in disasters

\begin{tabular}{|c|c|c|c|c|c|c|}
\hline \multirow[b]{2}{*}{ Responding to } & \multicolumn{6}{|c|}{ Confidence About Responding } \\
\hline & $\begin{array}{l}\text { Not at all } \\
\text { confident }\end{array}$ & $\begin{array}{l}\text { Mildly } \\
\text { confident }\end{array}$ & $\begin{array}{l}\text { Slightly } \\
\text { confident }\end{array}$ & Confident & $\begin{array}{l}\text { Very } \\
\text { confident }\end{array}$ & $\begin{array}{l}\text { Extremely } \\
\text { confident }\end{array}$ \\
\hline Disaster $(n=51), 70.8 \%$ & 1.9 & 1.9 & 3.8 & 34.6 & 51.9 & 5.8 \\
\hline \multirow[t]{3}{*}{ Mass casualties $(n=52), 72.2 \%$} & 2 & 2 & 5.9 & 43.1 & 35.3 & 11.8 \\
\hline & \multicolumn{6}{|c|}{ Participants Who Had Training } \\
\hline & $\begin{array}{l}\text { Not at all } \\
\text { important }\end{array}$ & $\begin{array}{l}\text { Mildly } \\
\text { important }\end{array}$ & $\begin{array}{l}\text { Slightly } \\
\text { important }\end{array}$ & Important & $\begin{array}{l}\text { Very } \\
\text { important }\end{array}$ & $\begin{array}{l}\text { Extremely } \\
\text { important }\end{array}$ \\
\hline After training $(n=50), 69.4 \%$ & 0 & 0 & 0 & 2 & 22 & 76 \\
\hline
\end{tabular}

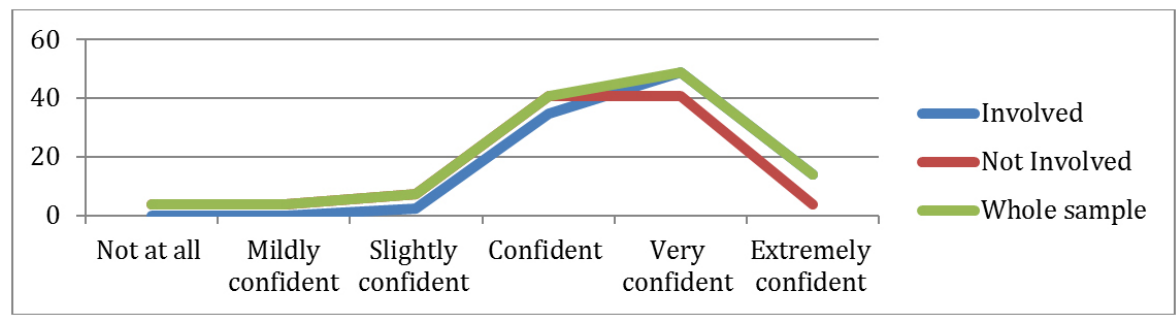

Figure 3. Confidence levels in preparedness for disaster among respondents with and without disaster training

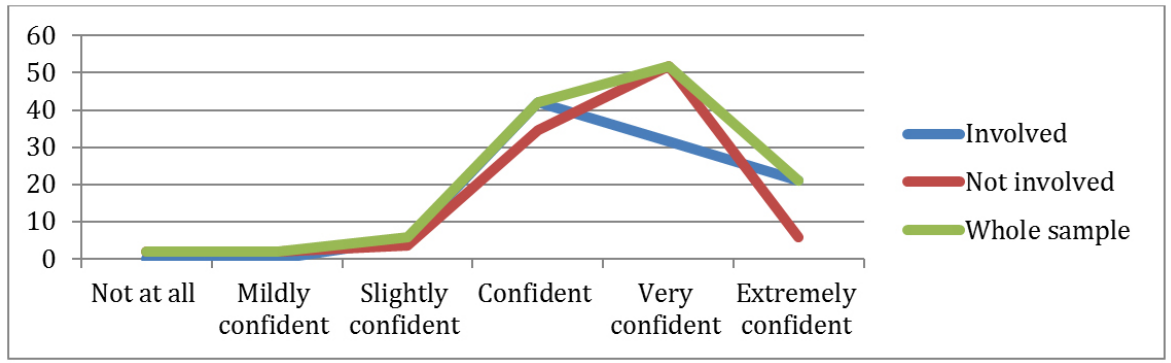

Figure 4. Confidence levels in preparedness for disaster among respondents with and without real disaster experience

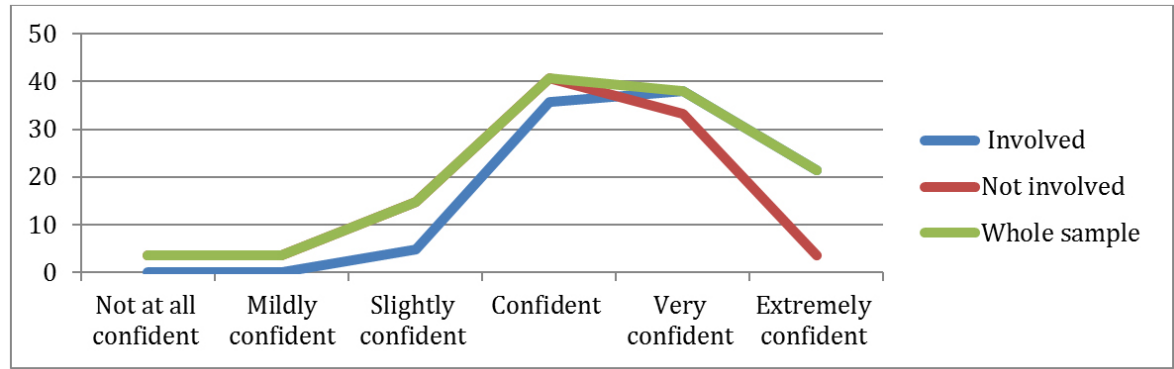

Figure 5. Confidence levels in preparedness for mass casualties among respondents with and without training

3.6 The importance of disaster training to those with and without real experience and with or without training

Those who had received training in disasters and mass casualties were statistically significantly more likely to rate training as being important $(\mathrm{Z}=-2.137, p=.03)$ than those who had not received training. These results are presented Published by Sciedu Press graphically in Figure 7.

With regard to the importance of disaster training, no statistically significant difference in ratings was found between respondents who had disaster experience and those who had none $(\mathrm{Z}=-1.772, p=.07)$. These results are presented graphically in Figure 8. 


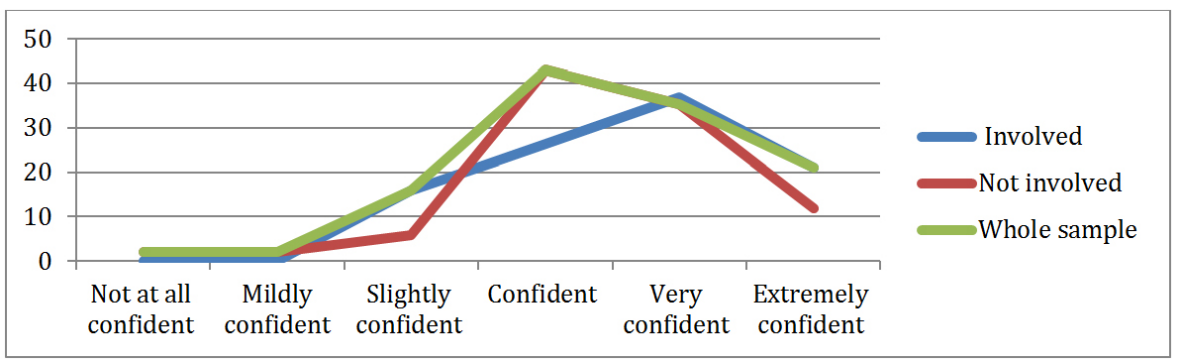

Figure 6. Confidence levels in preparedness for mass casualties among respondents with and without real mass casualty experience

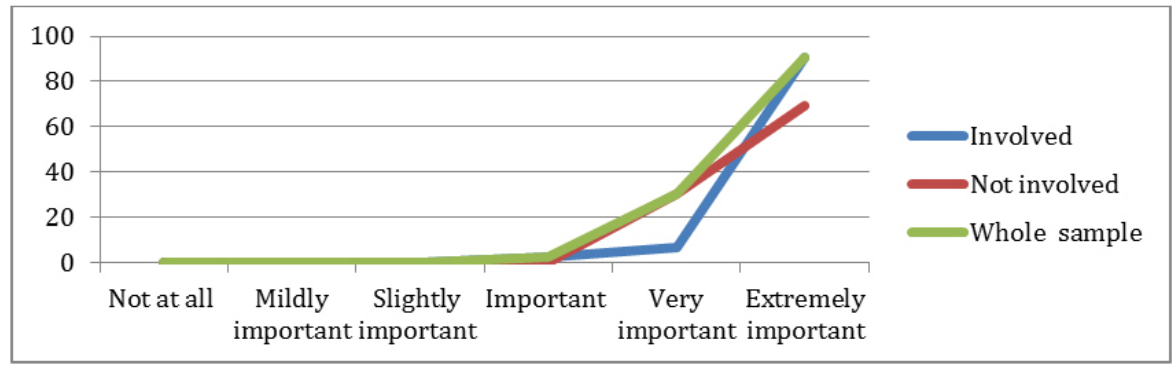

Figure 7. The importance of disaster training as rated by those with and without training

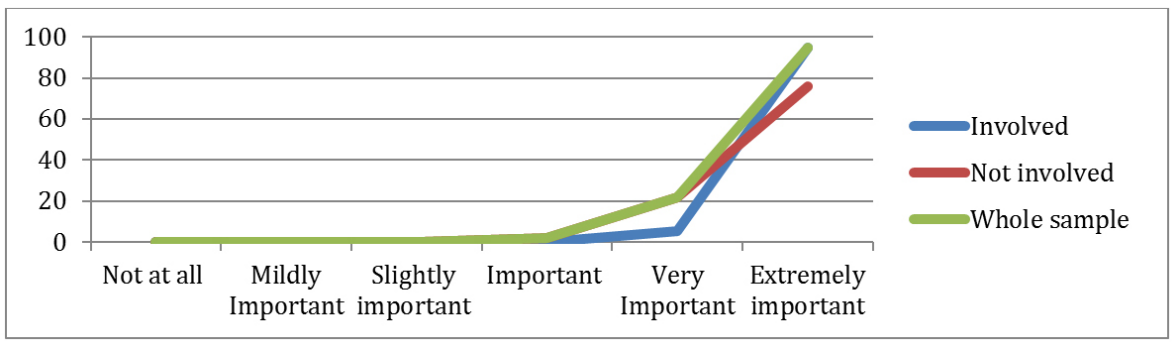

Figure 8. The importance of disaster training as rated by those with and without experience

\subsection{Respondents' recommendations}

In the open-ended question relating to future education and training, $90 \%$ of the respondents stated that disaster education and training should be improved, while $10 \%$ indicated that hospital policies need to be improved (see Table 10).

Table 10. Respondents' recommendations for future disaster training

\begin{tabular}{lll}
\hline Suggestions $(\boldsymbol{n}=\mathbf{1 0})$ & $\mathbf{N}$ & $\mathbf{\%}$ \\
\hline Improve education and training & 9 & 90 \\
Improve hospital policies & 1 & 10 \\
\hline
\end{tabular}

\section{Discussion}

\subsection{Introduction}

Disasters have become more frequent in the past 20 years. ${ }^{[3]}$

All healthcare workers who are on the front lines, including nurses, must be prepared for disasters. ${ }^{[5]}$ The liter- ature review of this study revealed that, although nurses seem to be unprepared to respond to disasters, they are willing to undertake training to improve their preparedness. ${ }^{[9,10,16,18,21,22,24,33-35]}$ Thus, the current study examined the disaster preparedness of emergency nurses working in health services in the KSA.

The previous chapter presented the study findings. In this chapter the main findings are discussed in the context of the literature review with reference to nurses' knowledge of hospital disaster plans, disaster education and training, confidence and experience. Finally, future work and the limitations of the study are discussed and the overall conclusion is presented.

\subsection{Knowledge of hospital disaster plans}

In the current study, the majority of nurses reported that they know the location of their hospital's disaster plan. In contrast, 
Whetzel et al. ${ }^{[24]}$ found that less than $10 \%$ of nurses knew the location of their hospital's disaster plan. Further, in the current study respondents report having read the plans and understood their role in disasters and major incidents, which concurs with the findings of several studies that also reported that nurses have read their hospital's disaster plans. ${ }^{[14,15]}$

In this study a very small minority of respondents stated that they did not understand their role after reading their hospital's disaster and major incidents plan. This result contrasts with that of Hammad et al., ${ }^{[16]}$ who found that almost all nurses in their study were confused about their role in the chain of command. Understanding hospital policy and disaster plans may improve nurses' knowledge and skills, and consequently, their preparedness to manage disaster events. ${ }^{[36]}$ This may be attributed to the length of hospital policies or the structure of the disaster plans themselves and how they are presented to nurses. Therefore, the policies and plans may need to be revised or updated. ${ }^{[37]}$ It is hard to reach a definitive conclusion as to why nurses were unable to understand their role after reading the disaster plan, and this may require further investigation. However, at this stage it may be reasonable to suggest simplifying the policy and presenting the role of nurses in a clear way. ${ }^{[5]}$

\subsection{Disaster education and training}

In the current study, more than half of the respondents reported that they received annual disaster training. Continuous disaster training is important, as it helps to refresh and update skills. ${ }^{[38]}$ Training should be provided to nurses on a regular basis, such as once or twice per year. Several studies agree on the importance of conducting regular training. ${ }^{[9,15,16]}$ The Joint Commission on Accreditation of Health Care Organizations ${ }^{[39]}$ recommends that all hospitals run two disaster drills per year, one table-top and one simulating an actual influx of patients, to be attended by all hospital staff, including nurses. ${ }^{[40]}$ However, the literature showed that nurses sometimes receive training infrequently. For instance, in the study by Hammad et al. ${ }^{[16]}$ a number of nurses reported that they had not received any disaster training in the past year and some had not received disaster training at all.

Further, the current study shows that more than half of the respondents received their training at tertiary hospitals in the form of hospital education sessions, and less than $5 \%$ of respondents received their training in the form of postgraduate courses and Saudi emergency medical incident courses. Hospital-based education may not be carefully provided to nurses for the following reasons: firstly, it tends to be lowcost site-based training that attempts to fulfil specific accreditation requirements; secondly, it tends to vary among different hospitals as it is mainly based on individual hospital needs. Al-Thobaity et al. ${ }^{[10]}$ compared nurses' preparedness in hospitals in different sectors and found that nurses' preparedness varied among different hospitals and different sectors. Such variation might result in inconsistent skill levels among nurses. The role of centrally-based education relating to disaster preparedness remains unclear. Regardless where the training takes place, it is essential that nurses at all hospitals are adequately trained and prepared. A future transition from peripheral hospital-based training to centrallybased training is another area that should be investigated with regard to nurse preparedness in the future.

\subsection{Confidence}

Of the respondents in this study, only a small number rated their confidence after being involved in training and cited their opinion of the training they undertook. The results showed that the confidence level of respondents who had undertaken disaster or mass casualties training was higher than that of those who had not. Further, respondents who had taken a disaster training course tended to perceive the training as important. This may indicate that the training gave those respondents extra skills and insights into managing disasters, leading to an increase in their confidence and belief in the importance of training. Both Duong ${ }^{[14]}$ and Powers ${ }^{[40]}$ pointed out that there is a proportional relationship between the amount of training that nurses receive and their level of confidence, that is, the less training nurses receive, the lower their confidence. A prepared nurse tends to feel confident that $\mathrm{s} /$ he can save lives in a real disaster. ${ }^{[41]}$ When nurses are adequately prepared, they feel sufficiently confident to respond to a disaster in a way that is organised, standardised and evidence-based.

Confidence was found to be a critical element in attending a real disaster incident. ${ }^{[22]}$ The current study found no significant difference in confidence between those respondents who had attended a real disaster or mass casualty experience (26\%) and those who had not. In contrast, Arbon et al. ${ }^{[11]}$ found that nurses who have frequently dealt with different types of disasters were more confident in responding to disaster events. This study did not investigate whether there was a significant relationship between the confidence level of those who had attended disaster training and that of those who had attended a real disaster. This requires further investigation. Arbon, Ranse, et al. ${ }^{[12]}$ found that participants in their study were willing to respond to a disaster, but factors like the nature of the disaster, their family situation and work environment may influence their willingness. According to the Oxford Dictionary, ${ }^{[42]}$ willingness is 'the quality or state of being prepared to do something'. This is likely to be a limitation of the training aspect, as the training sessions are not 
applicable to all types of disaster events. Since respondents may not be trained in all kinds of disaster incidents, they may feel unprepared when involved in a real disaster. ${ }^{[24]}$ Similarly, Manley et al. ${ }^{[17]}$ found that the perception of safety influences participants' willingness to become involved in a disaster, as respondents indicated that they were willing to deal with any kind of medical and surgical case (e.g., a patient cardiac emergency or motor vehicle event), but not with victims of radiation events.

\subsection{Disaster experience}

The respondents in the current study seem to have had minimal exposure to disaster experiences. Only 14 identified the type of disaster that they had experienced. Of these, 79\% reported that they had responded to a natural disaster (e.g., flood $=36 \%$ ) or mass casualty event (e.g., transport accidents $=43 \%$ ) during 2014. ${ }^{[43]}$ Duong $^{[14]}$ also considered motor vehicle accidents a type of disaster incident. This study did not determine the number of victims per disaster event as this data lay beyond the study's scope. However, the World Health Organization ${ }^{[44]}$ has stated that the KSA has the highest road traffic accident mortality rate in the world, and that, of every 32 people involved in a vehicle accident in the KSA, one was either injured or killed in massive accidents.

Of those who identified the type of disaster they had experienced, 36\% dealt with floods. This is not an unexpected result, since floods regularly occur in Riyadh. ${ }^{[45]}$ From the perspective of the health care system, disasters with advance notice, such as floods, may result in fewer victims. ${ }^{[46]}$

It is unclear why none of the nurses reported experience with biological threats, as the KSA experienced several hospital outbreaks of such threats as the Middle East respiratory syndrome coronavirus between 2012 and August 2015. ${ }^{[47]}$ The respondents in our study may not have considered these types of outbreaks biological disasters.

\subsection{Future work}

The current study has identified several areas for future investigation, some of which arose from the study findings and others from the discussion. In general, there is a paucity of research in the KSA about nurses' preparedness for disaster. Although the role of hospitals in disaster training and education is well acknowledged by respondents in the current study and the literature, the role of formal education is unclear and requires further investigation. There is also a potential need to emphasise the role of centrally-based education. Training should also take various forms, including table-top exercise drills.

This study investigated separately the confidence levels of those who had attended training sessions and those who had experienced a real disaster. Further investigation is required to identify whether there is a significant relationship between confidence after training and confidence after a real disaster. Although respondents were asked about the types of disaster incidents in which they had been involved, it was beyond the scope of the current study to investigate this in depth. This study showed that respondents may not be aware of the different types of disaster, and, in particular, may not know what to consider a disaster. This may also indicate areas in which nurses require additional training, such as biological threats. The limited disaster experience reported by respondents may influence their ability to respond to different types of disaster events. This highlights the need for a variety of disaster education and training courses.

\subsection{Limitations}

The limitations of this study include self-reporting, which may lead to bias. Respondent loss of interest appeared to influence the results, mainly in the open-ended questions at the end of the questionnaire, and the number of respondents who responded to questions throughout the questionnaire differed dramatically. For example, 72 respondents answered the demographic data items, 42 respondents answered the perception and confidence items and only 14 answered items in the final section of the questionnaire. This led to an increase in the number of missing values.

Another limitation is related to the sampling. The sample in the current study was small and selective, which dramatically limits the generalisability of the findings. It may also influence the research outcomes by obscuring existing statistically significant findings. This limitation was partly created by the regulations set by the administration of one of the hospitals during the distribution of the questionnaire. The hospital mandated that the researcher must provide two copies of the questionnaire (in Arabic and in English). The researcher was also not allowed to administer the questionnaire herself and had to rely on others to administer it through a lengthy process. Forty-nine respondents completed the Arabic copy of the questionnaire, although they were instructed not to answer in Arabic. Consequently, these submissions were ineligible because the MUHREC had not granted the study permission to use an Arabic questionnaire.

\section{Conclusion}

This study examined the disaster preparedness of emergency nurses working in health care services in the KSA. In particular, the study aimed to identify their level of confidence, knowledge, training and experience. The data were gathered from two hospitals in Riyadh. The study revealed that most respondents understood their role after reading the disaster 
plan. A small minority received their disaster education annually in a tertiary hospital in the form of education sessions. Less than half of the participants responded to items relating to perception and confidence. However, a statistically significant difference in confidence and perception was found between those who had undertaken disaster or mass casualties training and those who had not. At the same time, no significant difference in confidence was found between those who had attended a real disaster or mass casualties experience and those who had not.

Respondents had minimal disaster experience, which may explain why they did not feel confident about being involved in real disaster events. This highlights the need for continuous efforts to expand disaster training and ensure that nurses are properly prepared. Thus, this study helps to fill an existing knowledge gap in the literature, and may inform hospital managers, educators and nurses about the current state of nurses' knowledge and confidence.

\section{ACKNOWLEDgements}

I am especially grateful to Ms. Karen Hammad (née Duong) for her cooperation. She approved my using tools from her two studies as the basis for my study, and consistently answered my queries. I am also grateful to the Saudi Ministry of Health, which allowed me to conduct this survey. Thanks are due to the three subject matter experts Mr, Mohammad Al-Khalied, Mr, Suliamn Al-Hifdi and Miss Marim Alshaibe whose work made the questionnaire suitable for participants from the Kingdom of Saudi Arabia.

\section{CONFLicts OF InTEREST Disclosure}

The author declares that there is no conflict of interest.

\section{REFERENCES}

[1] What is a disaster? [Internet]. Geneva: International Federation of Red Cross and Red Crescent Societies. 2013. Available from: https://www.ifrc.org/en/what-we-do/disaster-m anagement/about-disasters/what-is-a-disaster/

[2] Iserson KV, Heine CE, Larkin GL, et al. Fight or flight: the ethics of emergency physician disaster response. Annals of Emergency Medicine. 2008; 51(4): 345-53. http://dx.doi.org/10.1016/j .annemergmed .2007.07.024

[3] What is the human cost of natural disasters? (1994-2013) [Internet]. Centre for Research on the Epidemiology of Disasters. 2015. Available from: http://www.cred.be/publication/credcrun $\mathrm{ch}-38$

[4] Mass casualty management systems [Internet]. Geneva: World Health Organization. 2007. Available from: http://www. who.int/hac/ techguidance/MCM_guidelines_inside_final.pdf

[5] Powers R, Daily E. International disaster nursing. New York, NY: Cambridge University Press. 2010.

[6] Disaster risk management for health [Internet]. Geneva: World Health Organization. 2011. Available from: http://www. who. int/hac/ events/drm_fact_sheet_overview.pdf

[7] Hollingsworth JC, Chisholm CD, Giles BK, et al. How do emergency physicians and nurses spend their time in the emergency department? Annals of Emergency Medicine. 1994; 31(1): 87-91. http://dx.doi.org/10.1016/S0196-0644(98) 70287-2

[8] The role of the occupational health nurse in workplace health management [Internet]. Geneva: World Health Organization. 2001. Available from: http://www. who.int/occupational_health/ regions/en/oeheurnursing.pdf

[9] Al-Khalaileh MA, Bond E, Alasad JA. Jordanian nurses' perception of their preparedness for disaster management. International Emergency Nursing, 2010; 20(1): 14-23. http://dx.doi.org/10.10 16/j.ienj.2011.01.001

[10] Al-Thobaity A, Plummer V, Innes K, et al. Perceptions of knowledge of disaster management among military and civilian nurses in Saudi Arabia. Australasian Emergency Nursing Journal, 2015; 18(3): 156-64. http://dx.doi.org/10.1016/j.aenj.2015.03.001

Published by Sciedu Press
[11] Arbon P, Cusack L, Ranse J, et al. Exploring staff willingness to attend work during a disaster: a study of nurses employed in four Australian emergency departments. Australasian Emergency Nursing Journal. 2013; 16(3): 103-09. http://dx.doi.org/10.1016/j . aenj . 2013.05.004

[12] Arbon P, Ranse J, Cusack L, et al. Australasian emergency nurses' willingness to attend work in a disaster: a survey. Australasian Emergency Nursing Journal. 2013; 16(2): 52-57. http://dx. doi .org /10.1016/j.aenj.2013.05.003

[13] Baack S, Alfred D. Nurses' preparedness and perceived competence in managing disasters. Journal of Nursing Scholarship. 2013; 45(3): 281-87. http://dx.doi.org/10.1111/jnu. 12029

[14] Duong K. Disaster education and training of emergency nurses in South Australia. Australasian Emergency Nursing Journal. 2009; 12(3): 86-92. http://dx.doi.org/10.1016/j.aenj.2009.05. 001

[15] Fung OWM, Loke AY, Lai CKY. Disaster preparedness among Hong Kong nurses. Journal of Advanced Nursing. 2008; 62(6): 698-703. http://dx.doi.org/10.1111/j.1365-2648.2008.04655.x

[16] Hammad KS, Arbon P, Gebbie KM. Emergency nurses and disaster response: an exploration of South Australian emergency nurses' knowledge and perceptions of their roles in disaster response. Australasian Emergency Nursing Journal. 2011; 14(2): 87-94. http: $/ /$ dx.doi.org/10.1016/j.aenj.2010.10.002

[17] Manley WG, Furbee PM, Coben JH, et al. Realities of disaster preparedness in rural hospitals. Disaster Management \& Response. 2006; 4(3): 80-87. http://dx.doi.org/10.1016/j.dmr.2006.05.0 01

[18] Melnikov, et al. Israeli nurses' intention to report for work in an emergency or disaster. Journal of Nursing Scholarship. 2014; 46(2): 134-142. http://doi:10.1111/jnu.12056.2014

[19] Mitchell CJ, Kernohan WG, Higginson R. Are emergency care nurses prepared for chemical, biological, radiological, nuclear or explosive incidents? International Emergency Nursing. 2012; 20(3): 151-61. http://dx.doi.org/10.1016/j.ienj.2011.10.001

[20] Ranse J, Lenson S, Aimers B. Black Saturday and the Victorian bushfires of February 2009: a descriptive survey of nurses who as- 
sisted in the pre-hospital setting. Collegian. 2010; 17(4): 153-59. http://dx.doi.org/10.1016/j.colegn.2010.08.002

[21] Rassin M, Avraham M, Nasi-Bashari A, et al. Emergency department staff preparedness for mass casualty events involving children. Disaster Management \& Response. 2007; 5(2): 36-44. http: $/ /$ dx.doi.org/10.1016/j.dmr.2007.03.002

[22] Usher K, Mills J, West C, et al. Cross-sectional survey of the disaster preparedness of nurses across the Asia-Pacific region. Nursing and Health Sciences. 2015; 17(4): 434-43. http://dx.doi.org/10. $1111 /$ nhs. 12211

[23] Wenji Z, Turale S, Stone TE, et al. Chinese nurses' relief experiences following two earthquakes: Implications for disaster education and policy development. Nurse Education in Practice. 2015; 15(1): 75-81. http://dx.doi.org/10.1016/j.nepr.2014.06.011

[24] Whetzel E, Walker-Cillo G, Chan GK, et al. Emergency nurse perceptions of individual and facility emergency preparedness. Journal of Emergency Nursing: Official Publication of The Emergency Department Nurses Association. 2013; 39(1): 46-52. http: //dx.doi.org/10.1016/j.jen.2011.08.005

[25] Yin $\mathrm{H}, \mathrm{He} \mathrm{H}$, Arbon P, et al. Optimal qualifications, staffing and scope of practice for first responder nurses in disaster. Journal of Clinical Nursing. 2011; 21(1-2): 264-71. http://dx.doi .org/10 $1111 / j .1365-2702.2011 .03790 . x$

[26] Veenema TG, Walden B, Feinstein N, et al. Factors affecting hospitalbased nurses' willingness to respond to a radiation emergency. Disaster Medicine and Public Health Preparedness. 2008; 2(4): 224-29. http://dx.doi.org/10.1097/DMP. Ob013e31818a2b7a

[27] Al-Amri YA. Emergency management in Saudi Arabia: past, present and future [Internet]. Christchurch (NZ): Christchurch School of Medicine, University of Otago and Van der Veer Research Institute. 2010. Available from: https: //training.fema.gov/hiedu/downloads/compemmgmtbook project/comparativeembook-eminsaudiarabia.pdf

[28] Al-Mazroa MA, Memish ZA, Al-Wadey AM. Pandemic influenza A (H1N1) in Saudi Arabia: description of the first one hundred cases. Annals of Saudi Medicine. 2010; 30(1): 11-14. http://dx.doi.o $\mathrm{rg} / 10.4103 / 0256-4947.59366$

[29] De Groot RJ, Baker SC, Baric RS, et al. Middle East Respiratory Syndrome Coronavirus (MERS-CoV): Announcement of the Coronavirus Study Group. Journal of virology . 2013; 87(14): 7790-7792. PMid:23678167 http://dx.doi.org/10.1128/JVI.01244-13

[30] Al-Malki M, Fitzgerald G, Clark M. Health care system in Saudi Arabia: an overview. Eastern Mediterranean Health Journal. 2011; 17(10): 784-93. PMid:22256414

[31] Creswell JW. Research design, qualitative, quantitative, and mixed: methods approaches. 2nd ed. Thousand Oaks (CA): Sage; 2003.

[32] Pallant J. SPSS survival manual: a step by step guide to data analysis using SPSS. 5th ed. England: McGraw-Hill International. University Press; 2013.

[33] Fung WMO, Lai KYC, Loke AY. Nurses' perception of disaster: implications for disaster nursing curriculum. Journal of Clinical Nursing. 2009; 18(22): 3165-71. http://dx.doi.org/10.1111/j.1 $365-2702.2008 .02777 . x$
[34] Ranse J, Arbon P, Shaban R, et al. Understanding the willingness of Australian emergency nurses to respond to a health care disaster. Australasian Emergency Nursing Journal. 2010; 13(4): 138 http://dx.doi.org/10.1016/j.aenj.2010.08.267

[35] Wetta-Hall R, Fredrickson DD, Ablah E, et al. Knowing who your partners are: terrorism-preparedness training for nurses. Journal of Continuing Education in Nursing. 2006; 37(3): 106-12. http: //dx.doi.org/10.3928/00220124-20060301-03

[36] Jagim M. Emergency preparedness response: Building infrastructure. Journal of Emergency Nursing. 2007; 33(6): 567-570. http://doi : $10.1016 / j \cdot$ jen. 2007.08 .013

[37] Considine J, Mitchell B. Chemical, biological and radiological incidents: preparedness and perceptions of emergency nurses. Disasters. 2009; 33(3): 482-97. http://dx.doi.org/10.1111/j.1467-7 $717.2008 .01084 . \mathrm{x}$

[38] Wang C, Wei S, Xiang H, et al. Evaluating the effectiveness of an emergency preparedness training programme for public health staff in China. Public Health. 2008; 122(5): 471-77. http://dx. doi.o $\mathrm{rg} / 10.1016 / \mathrm{j}$. puhe .2007 .08 .006

[39] Outrunning disaster: NYC Marathon serves as a model of mass casualty planning for hospitals [Internet]. Oakbrook Terrace (IL): Joint Commission in Accreditation of Health Care Organizations. 2015. Available from: https://www.jcrinc.com/my-account /free-resources/

[40] Powers MF. Evaluation of hospital-based disaster education. Journal of Emergency Nursing. 2007; 33(1): 79-82. http://dx.doi.org $/ 10.1016 / j \cdot j$ jen.2006.10.008

[41] Bartley BH, Stella JB, Walsh LD. What a disaster?! Assessing utility of simulated disaster exercise and educational process for improving hospital preparedness. Prehospital and Disaster Medicine. 2006; 21(4): 249-55. PMid:17076425 http://dx.doi.org/10.1017/S $1049023 \times 00003782$

[42] Willingness [Internet]. Oxford Dictionaries. 2015. Available from: http://www.oxforddictionaries.com/definition/ english/willingness

[43] Healthy people 2020 [Internet]. Centers for Disease Control and Prevention. 2010. Available from: http://www.cdc.gov/nchs/dat a/hpdata2010/hp2010_final_review.pdf

[44] Global status report on road safety 2009 [Internet]. Geneva: World Health Organization. 2009. Available from: http://www. who.int/violence_injury_prevention/road_ safety_status/2009/en

[45] Nahiduzzaman KM, Aldosary AS, Rahman MT. Flood induced vulnerability in strategic plan making process of Riyadh city. Habitat International. 2015; 49: 375-85. http://dx. doi.org/10.1016/j .habitatint.2015.05.034

[46] Hassmiller SB, Stanley S. Public health nursing and the disaster management cycle. Public Health Nursing. Missouri (MO): Mosby; 2012: 507-31.

[47] Mackay IM, Arden KE. Middle East respiratory syndrome: an emerging coronavirus infection tracked by the crowd. Virus Research. 2015; 16(202): 60-88. http://dx.doi.org/10.1016/j.virusres . 20 15.01 .021 